\title{
OCCURRENCE OF THE SKIN FORM OF MAREK'S DISEASE AND ITS RELATION TO THE AGE OF SLAUGHTERED BROILERS*
}

\author{
V. JURAJDA and O. KAVELA \\ Department of Poultry, Fish, Bee and Game Diseases, University of Veterinary Science, 61242 Brno \\ and South-Moravian Poultry Industry, Velké Pavlovice
}

Received March 2, 1981

\begin{abstract}
Jurajda V., O. Kavela: Occurrence of the Skin Form of Marek's Disease and its Relation to the Age of Slaughtered Broilers. Acta vet. Brno 51, 1982:117-124.

An analysis of the occurrence of Marek's disease in broilers slaughtered in the years 1977-1979 in one poultry slaughter-house in the South-Moravian Region was carried out.

Marek's disease (MD) was detected in $0.9 \%$ of broilers slaughtered in 1977, in 0.8 and $0.73 \%$ of broilers slaughtered in 1978 and 1979, respectively. From those MD-positive chickens $1.91 \%$ of birds was condemned in $1977,3.94 \%$ in 1978 rising to $7.96 \%$ in 1979 . The other MD-positive chickens were evaluated as conditionally consumable. The main and often single finding in those birds was the skin form of $M D$, while visceral lymphoid tumours were observed only sporadically.

More detailed analysis of $\mathbf{4 7 9}$ flocks of broilers proved that infection rate of Marek's disease reached $85 \%$. Skin form of MD was determined in 304 flocks (63.47\%). Simultaneous occurrence of skin and visceral forms was determined in 101 flocks $(21.09 \%)$. In remaining 74 flocks $(15.45 \%)$ no macroscopical findings of $M D$ were determined after slaughter.

The occurrence of skin form of $M D$ in relation to the age of slaughtered broilers was studied in 55 flocks. The incidence of $\mathrm{MD}$ skin lesions war more frequent in the flocks of broilers slaughtered in 50-60 days of age than in the birds slaughtered in 61-67 days of age. The occurrence of visceral lymphoid tumours in those flocks varied from 0 to $0.63 \%$ and was not influenced by the age of slaughtered broilers.
\end{abstract}

Marek's disease, broilers, skin lesions, age.

Marek's disease (MD) is an economically important lymphoproliferative disease of poultry caused by herpesvirus. In infected chickens peripheral nerves have been affected and lymphoid tumours have been formed in visceral organs, muscles and skin.

The acute form of MD began to appear in Czechoslovakia at the beginning of 60 -ies (Haladej 1966) causing considerable losses of 200-300 millions Kčs per year. After vaccination with turkey herpes virus, the frequency of tumorous changes in poultry decreased considerably. But in non-vaccinated flocks of broilers, considerable losses have remained up to this time.

From about 1975 an increased occurrence of skin lesions in slaughtered and technologically processed broilers evaluated as a skin form of $M D$ has been determined in Czechoslovakia. The number and frequency of the occurrence of these changes vary considerably - in some slaughter houses and in several regions they reach high percentage, in other ones the occurrence is minimal or even this form of the disease is not detected at all. Opinions of veterinary-hygienic inspection concerning the evaluation of the meat of poultry affected with skin lesions are also widely different.

* This work was realized in collaboration and with support of the South-Moravian Poultry Industry, Velké Pavlovice. 
The aim of our work was to contribute to elucidation of the above-mentioned problems, as well as of several epizootiological features of the skin form of Marek's disease by means of long-term study of the occurrence of skin lesions in broilers slaughtered in one poultry slaughter-house in the South-Moravian"region. The presented work brings the analysis of obtained findings with reference to the relation of the occurrence of skin lesions to the age of slaughtered broilers.

\section{Materials and Methods}

The results of meat inspection of slaughtered broilers in relation to Marek's disease were followed and recorded in the years 1977-1979. Necessary data were obtained from veterinary poultry inspection at the slaughter-house.

For the determination of the relation of the age of slaughtered broilers to the occurrence of skin lesions two poultry farms with the highest capacity of broilers delivered for slaughtering, were chosen: farm A (broilers in cage batteries)and farm B (broilers on deep litter). Patho-anatomical findings after slaughter were recorded from July 1978 to the end of March 1980.

In the course of studied period histological examinations of the skin and peripheral nerves in chickens with marked macroscopic changes on the skin was carried out repeatedly; the chickens were picked out from randomly selected flocks of broilers (we are indebted to dr. R. Halouzka, from the Department of Pathological Anatomy of VŠV Brno for his kind performance of the histological examinations.)

In the statistical evaluation of results $X^{2}$ (chi) test was used for the Table $2 \times 2$ and the calculation of correlation coefficient according to Reis enauer (1965).

\section{Results}

The frequency of MD occurrence in broilers slaughtered in the years 1977-1979 is given in the Table 1 .

Marek's disease was detected in 1977 in $0.9 \%$ of slaughtered broilers, in 1978 and 1979 it was $0.8 \%$ and $0.73 \%$, respectively. From those MD-positive chickens $1.91 \%$ were condemned in $1977,3.94 \%$ in 1978 and as much as $7.96 \%$ in 1979. The rest of the chickens was evaluated as conditionally consumable.

In the years 1977-1978 the main and often single finding in chickens evaluated as conditionally consumable was the skin form of Marek's disease, while organs were affected only sporadically. In 1979 the occurrence of visceral lymphoid tumours increased up to $10 \%$, but the skin form of $\mathrm{MD}$ remained further the most frequent finding (Fig. 2 and 3 ).

During the lst half-year of 1979 more detailed analysis of the flocks delivered to the slaughter-house was carried out. From the total number of 479 examined

Table 1

Occurrence of Marek's disease (MD) in broilers slaughtered in the years 1977-79

\begin{tabular}{|c|c|c|c|c|c|c|c|c|c|}
\hline \multirow{3}{*}{ Year } & \multirow{3}{*}{$\begin{array}{c}\begin{array}{c}\text { Slaugh- } \\
\text { tered }\end{array} \\
\text { No. }\end{array}$} & \multirow{2}{*}{\multicolumn{2}{|c|}{$\begin{array}{l}\text { Total occurrence } \\
\text { of } \mathrm{MD} \text { in slaugh- } \\
\text { tered broilers }\end{array}$}} & \multirow{3}{*}{$\frac{\begin{array}{c}\text { Condemned } \\
\left.\text { for } M D^{1}\right)\end{array}}{\text { No. }}$} & \multicolumn{5}{|c|}{ Conditionally consumable poultry objected for MD } \\
\hline & & & & & \multirow{2}{*}{$\frac{\text { Total }}{\text { No. }}$} & \multicolumn{2}{|c|}{ Visceral MD } & \multicolumn{2}{|c|}{ Skin MD } \\
\hline & & No. & $\%$ & & & No. & $\%$ & No. & $\%$ \\
\hline \multirow[t]{2}{*}{$\begin{array}{l}1977 \\
1978 \\
1979\end{array}$} & $\begin{array}{l}5,743.849 \\
7,674.683 \\
8,092.890\end{array}$ & $\begin{array}{l}51.745 \\
61.688 \\
59.090\end{array}$ & $\begin{array}{l}0.90 \\
0.80 \\
0.73\end{array}$ & $\begin{array}{r}986 \\
2.429 \\
4.704\end{array}$ & $\begin{array}{l}50.759 \\
59.259 \\
54.386\end{array}$ & $\begin{array}{l}1.440 \\
1.778 \\
5.399\end{array}$ & $\begin{array}{l}2.84 \\
3.00 \\
9.93\end{array}$ & $\begin{array}{l}49.319 \\
57.481 \\
48.987\end{array}$ & $\begin{array}{l}97.16 \\
97.00 \\
90.07\end{array}$ \\
\hline & $21,511.422$ & 172.523 & 0.80 & 8.119 & 164.404 & 8.617 & 5.24 & 155.787 & 94.76 \\
\hline
\end{tabular}

1) In condemned broilers the occurrence of single MD-forms was not registered. 


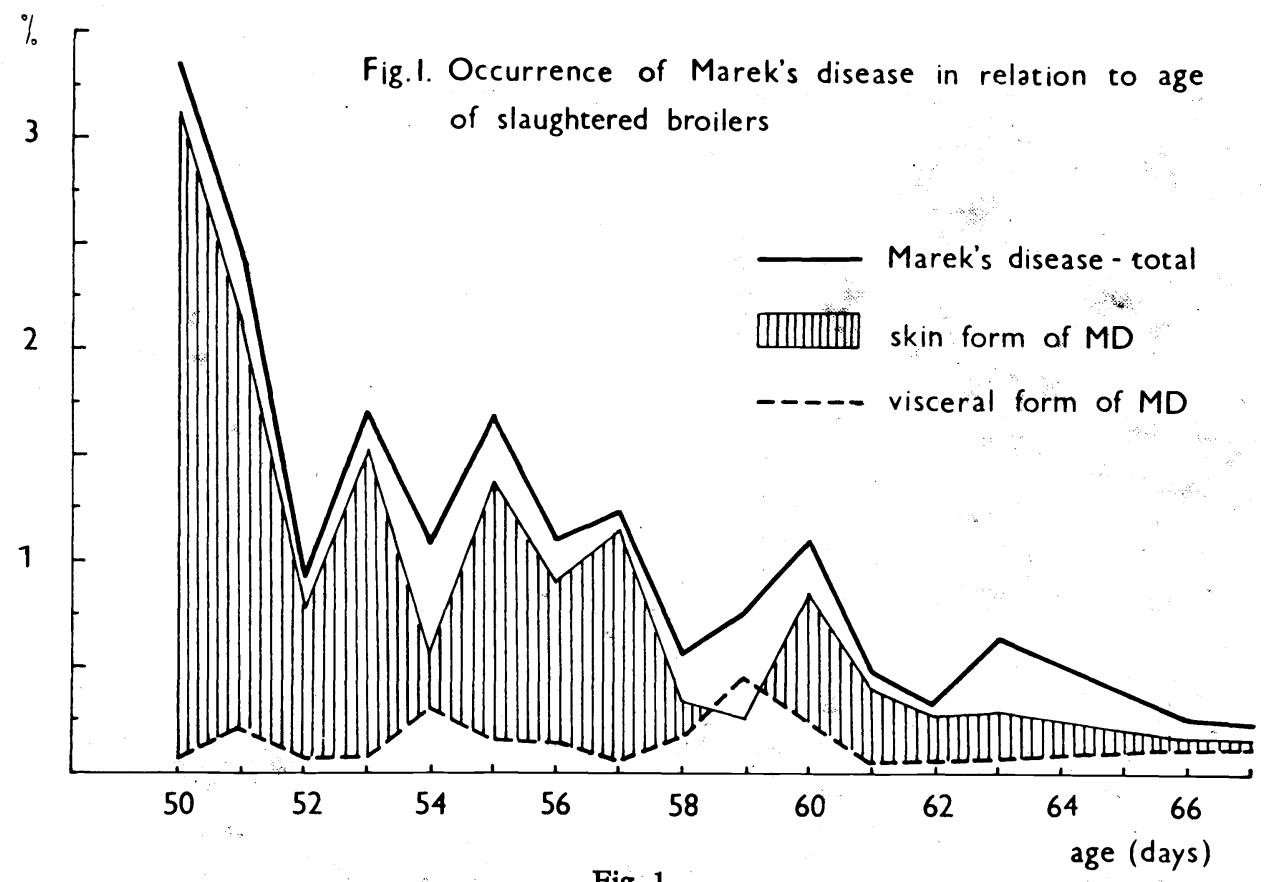

Occurrence of Marek's disease in relation to age of slaughtered broilers

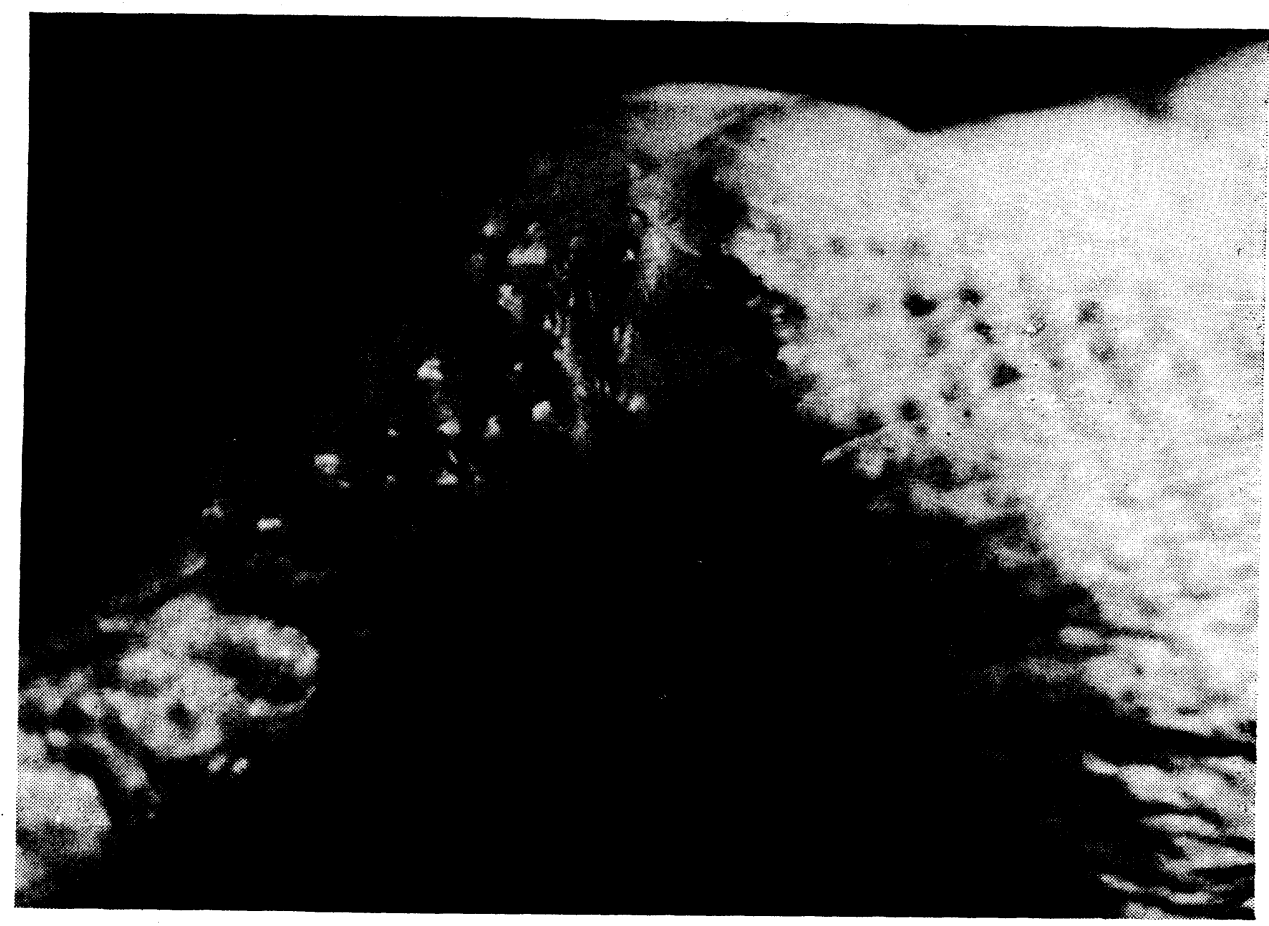

Fig. 2.

Tumorous changes of feather follicles on lateral side of the thigh. 


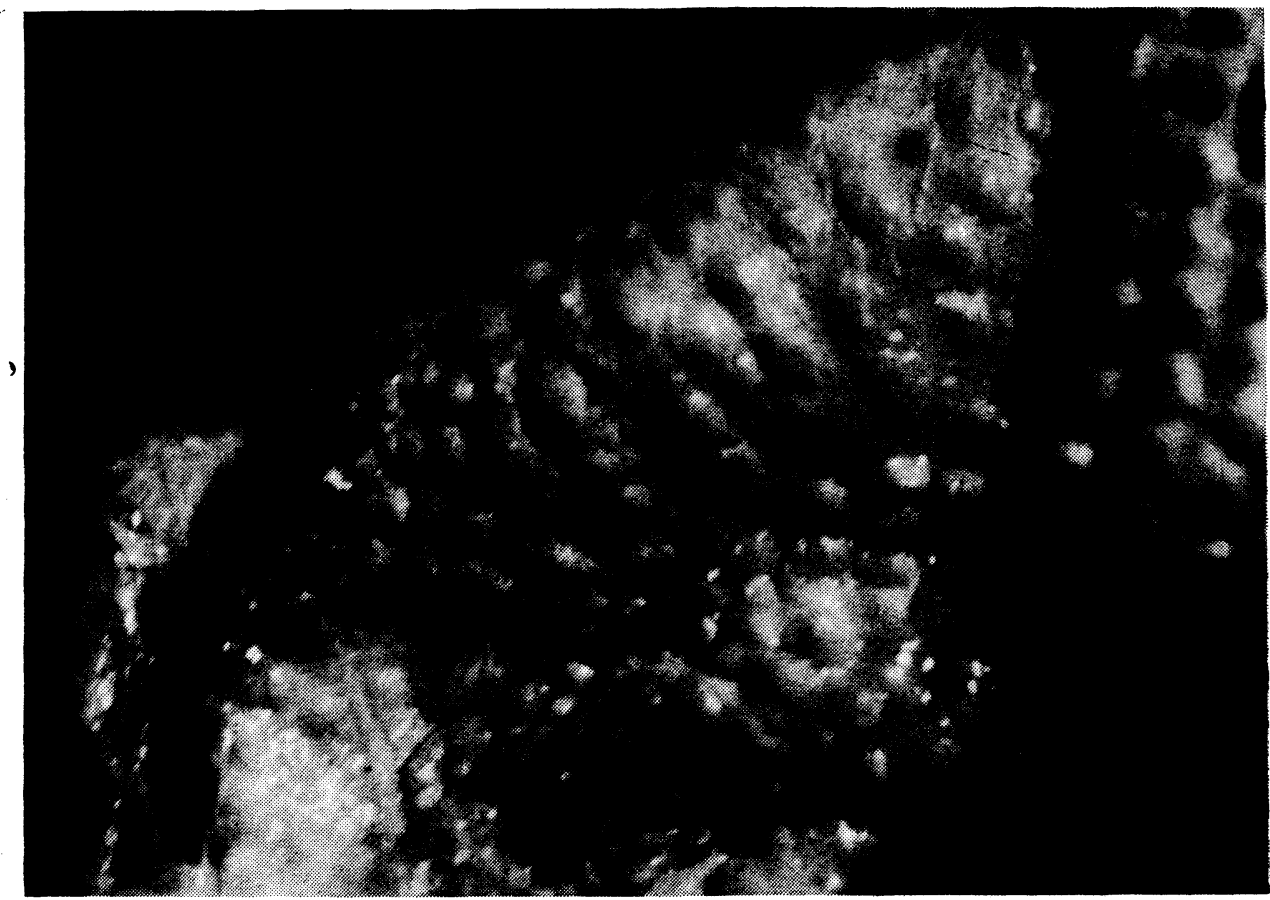

Fig. 3.

Tumorous changes of feather follicles on dorsal part of the skin of the neck and wings.

flocks (i. e. 3.800 .566 broilers in total) 74 flocks were free of macroscopic signs of MDV-infection. From remaining 405 flocks the skin form of MD was detected in 304 flocks, and simultaneous incidence of visceral and skin form of MD was detected in 101 flocks. Single occurrence of visceral form of MD, without the presence of skin lesions, was detected in none of 479 flocks of broilers.

In the flocks, where the incidence of skin lesions was very high $(5.6 \%$ and $6.28 \%$ of the slaughtered birds, resp.), visceral lymphoid tumours were not detected. On the other hand, in the flocks, where the occurrence of visceral tumours was very high $(1.25 \%$ and $2.63 \%$, resp.), skin lesions were detected in $1.86 \%$ and $2.92 \%$ of the slaughtered broilers, resp.

In 50 flocks selected randomly statistical evaluation of cross relation of the occurrence of skin and visceral lesions by means of the coefficient of correlation and $\mathrm{X}^{2}$ test was carried out. Both used tests confirmed the observed discordance between the occurrence of skin and visceral forms of MD.

Histological examination of 84 chickens affected with skin form of MD confirmed MD-specific lesions in peripheral nerves in $63.09 \%$ and in the skin in $96.43 \%$ of chickens. The scale of the histological findings in the skin was rather wide. Perivascular infiltrates of lymphoid cells of different size were detected in corium and around feather follicles. In epithelial sheath of the follicles striking dystrophic changes of cells of the corneal layer with presence of intranuclear inclusions were determined. In several cases a fusion of perivascular lymphoid clusters and dif- 
fused infiltration of the corium and subcutis with tumorous elements, as well as forming of lymphoid tumours were observed.

The results of the study of the effect of slaughtered broiler age on the occurrence of the skin form of Marek's disease are summarized in Table 2 and in Fig. 1.

A total of 55 flocks of broilers were studied, which means more than 2 millions chickens. Twenty one flocks of broilers from the farm A were slaughtered at 50 to 63 days of age and 34 flocks of broilers from the farm B were slaughtered at $52-67$ days of age, in total.

Visceral form of MD was not detected in 4 flocks, while skin lesions were determined in those flocks in $4.8 \%$ (the farm A, 53 days of age), in $4.85 \%$ and $0.9 \%$ (farms $A$ and $B$, age: 55 days), and in $0.44 \%$ (the farm B, 61 days of age) of the slaughtered chickens. In remaining 51 flocks the occurrence of the visceral form of $\mathrm{MD}$ ranged from $0.01 \%$ to $0.63 \%$.

The skin form of MD was not detected only in 2 flocks, while the visceral form appeared in those flocks coincidently in $0.8 \%$ chickens slaughtered at the age of 55 and 67 days, respectively, (both flocks were delivered from the farm B). In remaining flocks the occurrence of the skin form of $M D$ varied in the range of $0.02 \%$ to $4.85 \%$.

Only in 10 flocks ( 3 flocks from the farm A and 7 flocks from the farm B) the occurrence of visceral lymphoid tumours was higher than the occurrence of skin lesions in MD-positive chickens.

Table 2

Occurrence of Marek's disease in relation to the age of slaughtered broilers

\begin{tabular}{|c|c|c|c|c|c|c|c|c|c|}
\hline \multirow{2}{*}{$\begin{array}{c}\text { Age of } \\
\text { chickens } \\
\text { (days) }\end{array}$} & \multirow{2}{*}{$\begin{array}{c}\text { Slaughtered } \\
\text { chickens } \\
\text { (No.) }\end{array}$} & \multirow{2}{*}{$\begin{array}{c}\text { Number } \\
\text { of } \\
\text { flocks }\end{array}$} & \multirow{2}{*}{ Farm } & \multicolumn{2}{|c|}{$\begin{array}{l}\text { Visceral form } \\
\left.\text { of } M D^{1}\right)\end{array}$} & \multicolumn{2}{|c|}{$\begin{array}{l}\text { Skin form } \\
\text { of } M D^{1} \text { ) }\end{array}$} & \multicolumn{2}{|c|}{$\underset{\text { in } \text { total }^{2} \text { ) }}{M D}$} \\
\hline & & & & No. & $\%$ & No. & $\%$ & No. & $\%$ \\
\hline $\begin{array}{l}50 \\
51 \\
52 \\
53 \\
54 \\
55 \\
56 \\
57 \\
58 \\
59 \\
60 \\
61 \\
62 \\
63 \\
66 \\
67\end{array}$ & $\begin{array}{r}20.915 \\
224.592 \\
183.454 \\
44.122 \\
209.841 \\
181.876 \\
234.242 \\
54.247 \\
112.631 \\
135.232 \\
62.180 \\
45.571 \\
76.448 \\
43.955 \\
20.633 \\
66.867 \\
50.414 \\
45.158 \\
78.837 \\
22.724 \\
42.585 \\
53.306\end{array}$ & $\begin{array}{l}1 \\
3 \\
3 \\
2 \\
3 \\
2 \\
4 \\
3 \\
2 \\
7 \\
3 \\
1 \\
4 \\
1 \\
1 \\
3 \\
3 \\
2 \\
1 \\
1 \\
2 \\
3\end{array}$ & $\begin{array}{l}\text { A } \\
\mathbf{A} \\
\mathbf{A} \\
\mathbf{B} \\
\mathbf{A} \\
\mathbf{A} \\
\mathbf{A} \\
\mathbf{B} \\
\mathbf{A} \\
\mathbf{B} \\
\mathbf{B} \\
\mathbf{A} \\
\mathbf{B} \\
\mathbf{A} \\
\mathbf{B} \\
\mathbf{B} \\
\mathbf{B} \\
\mathbf{B} \\
\mathbf{A} \\
\mathbf{B} \\
\mathbf{B} \\
\mathbf{B}\end{array}$ & $\begin{array}{r}8 \\
446 \\
108 \\
33 \\
127 \\
535 \\
406 \\
26 \\
108 \\
199 \\
26 \\
110 \\
80 \\
267 \\
26 \\
158 \\
27 \\
20 \\
23 \\
11 \\
40 \\
46\end{array}$ & $\begin{array}{l}0.04 \\
0.20 \\
0.06 \\
0.07 \\
0.06 \\
0.29 \\
0.18 \\
0.05^{*} \\
0.10 \\
0.15^{*} \\
0.04 \\
0.24 \\
0.10^{*} \\
0.61 \\
0.13^{*} \\
0.24 \\
0.05 \\
0.04 \\
0.03 \\
0.05 \\
0.09 \\
0.09\end{array}$ & $\begin{array}{r}650 \\
4.675 \\
1.346 \\
401 \\
3.215 \\
987 \\
3.837 \\
137 \\
1.228 \\
1.006 \\
709 \\
76 \\
332 \\
89 \\
63 \\
569 \\
200 \\
119 \\
201 \\
69 \\
66 \\
68\end{array}$ & $\begin{array}{l}3.11 \\
2.08 \\
0.73 \\
0.90^{*} \\
1.53 \\
0.54 \\
1.64 \\
0.25^{*} \\
1.09 \\
0.74^{*} \\
1.14 \\
0.17 \\
0.43^{*} \\
0.20 \\
0.30^{*} \\
0.85 \\
0.40 \\
0.26 \\
0.26 \\
0.30 \\
0.15 \\
0.13\end{array}$ & $\begin{array}{r}700 \\
5.466 \\
1.580 \\
470 \\
3.571 \\
1.966 \\
4.652 \\
172 \\
1.489 \\
1.234 \\
762 \\
213 \\
473 \\
393 \\
90 \\
730 \\
241 \\
147 \\
560 \\
80 \\
108 \\
122\end{array}$ & $\begin{array}{l}3.35 \\
2.43 \\
0.86 \\
1.06^{*} \\
1.70 \\
1.08 \\
1.99 \\
0.32^{*} \\
1.32 \\
0.91^{*} \\
1.23 \\
0.47 \\
0.62^{*} \\
0.89 \\
0.44^{*} \\
1.09 \\
0.48 \\
0.33 \\
0.71 \\
0.35 \\
0.25 \\
0.23\end{array}$ \\
\hline & $\begin{array}{r}1,335.914 \\
673.916\end{array}$ & $\begin{array}{l}21 \\
34\end{array}$ & $\begin{array}{l}\mathbf{A} \\
\mathbf{B}\end{array}$ & $\begin{array}{r}2.138 \\
692\end{array}$ & $\begin{array}{l}0.16 \\
0.10^{*}\end{array}$ & $\begin{array}{r}16.304 \\
3.739\end{array}$ & $\begin{array}{l}1.22 \\
0.55^{*}\end{array}$ & $\begin{array}{r}20.590 \\
4.629\end{array}$ & $\begin{array}{l}1.54 \\
0.69^{*}\end{array}$ \\
\hline & $2,009.830$ & 55 & & 2.830 & 0.14 & 20.043 & 1.00 & 25.219 & 1.25 \\
\hline
\end{tabular}

1) Findings in conditionally consumable poultry.

2) Including condemned broilers, in which the occurrence of single MD-forms was not registered.

*) When evaluating by means of $\mathrm{X}^{3}$ (chí) test, statistically significant difference at $5 \%$ of significance level. 
Marek's disease was diagnosed macroscopically in all 55 studied flocks and its occurrence ranged in the flocks from $0.08 \%$ to $5.39 \%$, regardless of the age or the origin of broilers.

The incidence of skin lesions higher than $1 \%$ was more frequent in the flocks of chickens slaughtered at the age of 50-60 days, than in the flocks, where the broilers were slaughtered at the age of 61-67 days (Fig. 1). Significantly higher occurrence of Marek's disease, in both forms, was determined in the farm A (Table 2).

The connection between the age of slaughtered broilers and the occurrence of the skin form of MD showed an indirect ratio $(\mathrm{r}=-0.4279$ when $p<0,01)$ and was characterized by a regression line $y=7.1909-0.1105 x$.

\section{Discussion}

The analysis of MD occurrence showed high infection rate in the flocks of broilers slaughtered in the years 1977-1979 in the South-Moravian region. Predominant findings occurring in MD-positive chickens were skin lesions. Visceral lymphoid tumours were detected only sporadically.

Skin lesions connected with Marek's disease are known from 1963, when $\mathrm{Helm}$ boldt et al. (1963) described in the U. S. A. increased number of findings of so-called ,skin leukosis“, denominated later on as a skin form af acute Marek's disease (Purchase and Biggs 1967).

Studies dealing with the occurrence and epizootiology of the skin form of MD in commercial flocks are rather rare in literature. Lapen and Kenzy (1972) observed the occurrence of visceral tumours in $72.8 \%$ and skin lesions in $13.5 \%$ of chickens after experimental infection. Witter et al.(1970) studied the occurrence of Marek's disease in commercial flocks of broilers, where the total frequency of $M D$ ranged from 6 to $15.3 \%$ and skin lesions were determined in $85 \%$ from the total number of MD-positive chickens. But the findings of skin lesions in those broilers were accompanied in high percentage with the occurrence of visceral lymphoid tumours. The chickens were slaughtered at the age of 57-60 days and MDmortality rate during the growing period varied from 0 to $0.6 \%$.

The occurrence of acute Marek's disease in the flocks of broilers studied in our work was, however, characterized by predominant findings of skin lesions with comparatively low total incidence of $M D$ in single flocks and without any correlation to the occurrence of visceral lymphoid tumours. As far as we know, similar type of the occurrence of the skin form of MD has not been presented in literature.

It is well-known that susceptibility of chickens to MD is different (Cole 1968; Morris et al. 1970). Lapen and Kenzy (1972) present that in more susceptible chickens the occurrence of tumours in skin is more frequent. Considering that in Czechoslovakia Ross meat hybrids of the same origin are used predominantly for fattening and that in other slaughter-houses annual occurrence of MD in broilers varied about $2-6 \%$ in the years $1977-1979$, with simultaneous incidence of skin and visceral changes, it seems possible that genetic factors may be excluded.

Some data from practice show that shortening of the feeding period may decrease the occurrence of visceral tumours, however but with a simultaneous rise of $\mathrm{MD}$ skin lesions. As to the occurrence of skin lesions, our findings agree with these data (Table 2 and Fig. 1) although the relation between the age of slaughtered broilers and the occurrence of the visceral form of $M D$ was not proved. 
On the other hand, Kenzy and Lapen (1972) studied the effect of prolonged feeding period on the occurrence of skin lesions. They found either increased numbers of skin lesions, or its effect was not significant. It seems probable that the difference of these results in comparison with our findings could be caused by a longer test period in their experiments.

Significant difference in the occurrence of single forms of acute $M D$ in the farms $A$ and $B$ could be caused by different feeding technologies, but final conclusions without further studies seem to be premature.

We suppose that the described occurrence of skin lesions in MD-positive chickens in the South-Moravian Region in the years 1977-1979 without or with minimal affection of visceral organs is due to shorter feeding period of broiler flocks. Skin lesions, which seem to be one of the first signs of patho-morphological changes in MD-affected chickens, regress probably gradually and with increasing age of chickens the occurrence of visceral lymphoid tumours is still more frequent.

\section{Acknowledgements}

We wish to thank to dr. M. Pokorná and dr. J. Švestka for collaboration and Mrs. K. Jahodová for technical assistance.

\section{Výskyt kožní formy Markovy nemoci a jeho vztah ke stáří poražených brojlerů}

Byla provedena analýza výskytu Markovy nemoci u brojlerů poražených v letech 1977-1979 na jedné porážce v Jihomoravském kraji.

Markova nemoc (MD) byla pozorována v roce 1977 u 0,9\%, v roce 1978 u 0,8\% a v roce 1979 u $0,73 \%$ z poražených brojlerů. $Z$ těchto $M D$-pozitivních kuřat bylo v roce 1977 konfiskováno $1,91 \%$, v roce $19783,94 \%$ a v roce 1979 již $7,96 \%$. Ostatní kuřata byla posouzena jako podmíněně poživatelná. Hlavním a často $i$ jediným nálezem byla kožní forma $M D$, zatímco viscerální lymfoidní nádory se vyskytovaly jen ojediněle.

Detailnější analýza 479 turnusů brojlerů prokázala $85 \%$ promořenost chovů Markovou nemocí. Pouze kožní forma MD byla zjištěna u 304 turnusů $(63,47 \%$ ). Současný výskyt kožní a orgánové formy byl pozorován u 101 turnusủ $(21,09 \%)$. U zbývajících 74 turnusů $(15,45 \%)$ nebyly zjištěny po poražení makroskopické príznaky MD.

Výskyt kožní formy $M D$ ve vztahu ke stáří poražených brojlerů byl studován u 55 turnusů brojlerŭ. Frekvence MD-kožních změn byla častějši u turnusů poražených ve stáří $50-60$ dní, než u turnusů ve stáří $61-67$ dní. Výskyt viscerálních lymfoidních nádorů se pohyboval u jednotlivých turnusů od 0 do $0,63 \%$ a nebyl ovlivňován stář́m poražených brojlerů.

Závislost mezi stáŕím poražených brojlerů a výskytem kožní formy $M D$ vykazovala nepř́mý vztah $(r=-0,4279$ při $p<0,01)$ a byla charakterizována regresní př́mkou $y=7,1909-0,1105 x$. 
Наличие кожной формы болезни Марека и его отношение к возрасту битых бройлеров

Был проведен анализ наличия болезни Марека у бройлеров, битых в период 1977-1979 гг. на одном из убойных пунктв в Южно-Моравской области.

Болезнь Марека наблъдалась в 1977 г. у 0,9 \%, в 1978 г. - 0,8 \% и в 1979 г. - 0,73 \% битых бройлеров. Из упомянутых џыплят с положительными симптомами было в 1977 г. забраковано 1,91 \%, в 1978 г. - 3,94\% и в 1979 г. уже 7,96 \%. Остальные цыплята были оценены в качестве условно потребляемых. Главным и зачастую единственным проявлением была кожная форма болезни Марека, между тем как висцеральные лимфоидные опухоли имели место лишь в отдельных случаях.

Более детальный анализ 479 туров бройлеров выявил 85 \% зараженность ризвлдок болезнью Марека. Лишь ее кожная форма была установлена у 304 туров $(63,47 \%)$. Одновременное наличие кожной и органической форм наблюдалось у 101 тура $(21,09 \%)$. У остальных 74 туров $(15,45 \%)$ после умерщвления не были выявлены макроскопические признаки болезни Марека.

Наличие кожной формы болезни Марека по отношению к возрасту битых бройлеров изучалось на 55 турах бройлеров. Частота кожных изменений в результате данной болезни наблюдалась чаще у туров, битых в возрасте 5060 дней, чем у туров в возрасте $61-67$ дней. Наличие виспцеральных лимфоидных опухолей у отдельных туров достигало пределов $0-0,63 \%$ и не них не оказывал влияния возраст битых бройлеров.

Зависимость между возрастом битых бройлеров и наличием болезни Марека отличалась косвенным отношением ( $\mathbf{r}=0,4279$ при $\mathbf{r}<0,01)$ и была характеризована регрессионной прямой $\mathrm{y}=7,1909-0,1105 \mathrm{X}$.

\section{References}

COLE, R. K.: Studies on genetic resistance to Marek's disease. Avian Diseases, 12, 1968: 9-28.

HALADEJ, S.: Výskyt a rozšírenie najčastejšie zistovaných chorôb hydiny v CSSR. Ph.D. Thesis, VF Košice, 1966.

HELMBOLDT, C. F. - WILLS, F. K. - FRAZIER, M. N.: Field observations of the pathology of skin leukosis in Gallus gallus. Avian Dis., 7, 1963: 402-411.

KENZY, S. G. - LAPEN, R. F.: Pathogenesis of gross cutaneous Marek's disease chronological parameters. In: Oncogenesis and Herpesviruses, IARC, Lyon, 1972: 51-53.

LAPEN, R. F. - KENZY, S. G.: Distribution of gross cutaneous Marek's disease lesions. Poultry Sci., 51, 1972: $334-336$.

MORRIS, J. R. - FERGUSON, A. E. - JEROME, F. N.: Distribution of Marek's disease lesions in tissues and organs of Columbian Plymouth Rocks selected for resistance and susceptibility to induced Marek's disease infection. Can. J. Anim. Sci., 50, 1970: 83-88.

PURCHASE, H. G. - BIGGS, P. M.: Characterization of five isolates of Marek's disease. Res. Vet. Sci., 8, 1967: 440-449.

REISENAUER, R.: Metody matematické statistiky a jejich aplikace. SNTL Praha, 1965, 210 p.

WITTER, R. L. - MOULTHROP, J. I. - BURGOYNE, G. H. - CONNELL, H. C.: Studies on the epidemiology of Marek's disease herpesvirus in broiler flocks. Avian Dis., 14, 1970: $254-267$. 